\title{
The Influence of SMMEs Internal Factors on E-commerce Adoption: A South African Perspective
}

\author{
Mr Patrick Ndayizigamiye \\ University of KwaZulu-Natal, South Africa, School of Management, IT and Governance \\ Ndayizip@ukzn.ac.za
}

\section{Doi:10.5901/mjss.2014.v5n23p246}

\section{Abstract}

In South Africa, there is evidence of continued growth of internet users. This signifies that there is an increase of potential internet users who may be interested in conducting online transactions. The South African government, recognizing the importance that e-commerce plays in SMMEs business, has introduced an initiative to stimulate SMMEs online presence. The Woza online ${ }^{1}$ is platform that enables SMMEs to create their website using the .co.za domain. This move echoes authors that suggested that in order to thrive in the increasing digital economic environment, SMMEs must have an online presence. Following the same trend, this paper seeks to contribute to the knowledge of SMMEs internal factors that need to be taken into consideration in order to stimulate the growth of e-commerce adoption by SMMEs in the South African context. To this end, a survey was conducted amongst 400 SMMEs in Pietermaritzburg and Durban areas. Based on literature search, the following factors were identified as internal factors that influence e-commerce adoption: Firm's characteristics, Owner/manager characteristics and Internal IT capabilities. The influence of these factors on the adoption of the following 4 e-commerce was then assessed: i) customers payment by credit card through the SMME's website, ii) customers placing orders through the SMME's website, iii) providing customer services through the SMME's website and iv) placing orders with suppliers over the internet. Using convenience sampling, data was collected by means of questionnaires administered to 400 SMME owners/managers. Usable responses were collected from 360 SMME owners/managers. This represents a 90\% response rate. Findings reveal that SMMEs size, compatibility of e-commerce with company's' preferred work practices, compatibility of ecommerce with company's values are the firm's characteristics that influence e-commerce adoption in the selected SMMEs. In addition, Owner/Manager enthusiasm about e-commerce adoption is the Owner/Manager characteristic that significantly influences the adoption of e-commerce in the surveyed SMMEs. This characteristic is moderated by age in both locations. However, there is no significant relationship between internal IT capabilities and e-commerce adoption.

Keywords: e-commerce adoption, South Africa, SMME, internal factors

\section{Introduction}

Poon and Swatman (1999:9) define e-commerce as "sharing of business information, maintaining business relationships, and conducting business transactions by means of internet based technology."

A recent South African Mobile Report indicates that $80.2 \%$ internet users in South Africa access internet using their smart phones compared to 19.8\% who use the traditional desktop-based internet access (lab, 2014). The increase in internet adoption via mobile devices is an opportunity for firms that seek to establish an online customer base. The same report highlights that $20 \%$ of smart phone owners perform banking and other finance related purchases via their devices and $50 \%$ of them have been exposed to mobile-based advertisement. In addition, South Africa has $68 \%$ of internet users who access the internet daily (PRC, 2014). A number of SMMEs have responded to the call to have an online presence in order to leverage the increasing number of internet users across the country. A 2012 survey (Goldstuck, 2012) revealed that e-commerce was growing at a 30\% rate per year with predictions of increased growth in the following years. The survey revealed that $63 \%$ of SMMEs that are trading in the formal sector (410.000 SMMEs) had a website. The study also reveals a positive impact of online presence on SMMEs business. According to Goldstuck (2012), 150.000 SMMEs would have closed their businesses if they did not have an online presence. The closure of such businesses would have had a significant bad influence on the S.A. economy and job market. As SMMEs contribute to 7.8 million jobs (Goldstuck, 2012), such loss of SMMEs businesses would translate into 1.56 million of job losses (Goldstuck, 2012). The lack of

${ }^{1}$ Woza online is a platform (created through a joint venture between South African Department of Trade and Industry, Vodacom, the Human Resources Development Council and Google) that enables SMMEs to create their own websites through easy-to-follow steps without any cost (Goldstuck, 2012). 
SMMEs online presence would put them in jeopardy of extinction. It is in this context of the preponderant role of ecommerce that this paper examines SMMEs internal factors that influence e-commerce adoption within the South African context. The paper seeks to identify such factors and then provides suggestions on how to leverage such factors in order to increase the rate of e-commerce adoption by SMMEs in South Africa.

\section{Literature Review}

Various authors have identified a number of internal factors that affect a firm's ICT adoption. However, this paper focuses only on those that are specifically relevant to SMMEs. These can be classified as firm's characteristics, firm's organisational culture, owner/manager characteristics, and internal IT capabilities.

\subsection{Firm's characteristics}

\subsubsection{Firm size}

Van Beveren and Thomson (2002) conducted a survey of manufacturers with the aim of finding out whether the firm size could be one of the determinants of e-commerce adoption. The study reveals that small firms are less likely to adopt ecommerce than larger firms. The major impediment that influences such trend is the lack of skilled human resources to manage web-related tasks of small firms. However, the study used small sample sizes in some instances without case studies or empirical evidence to support the argument.

In contrast, MacGregor and Vrazalic (2005) presented a contrary result to that of Van Beveren and Thomson (2002). The findings from their study show that Swedish and Australian small businesses, especially old small businesses, tend to implement e-commerce due to affordability. Moreover, findings from the study of Al Qirim (2005) present mixed results based on different types of adopters. For starters ${ }^{2}$, firm size appears to be insignificant in the adoption of e-commerce by New Zealand SMMEs. However, firm size plays a major role on the adoption of e-commerce technologies for innovators ${ }^{3}$ and extended innovators 4 in New Zealand.

Hong and Zhu (2006) presented a different aspect of firm size as a control variable instead of an independent variable as used by Al Qirim (2005). Based on the Technology-Organisation-Environment (TOE) framework, they found that firm size is one of the factors in the organisational context that has some effects on IT adoption. Most importantly, Hong and Zhu (2006) empirical study indicates that firm size is negatively related to e-commerce adoption both in the Business to Business (B2B) and Business to Consumer(B2C) e-commerce environment.

\subsubsection{Firm's organisational culture}

Dharmayanti, Coffey and Trigunarsyah (2011:1) define organisational culture as "a set of values and norms that are shared by people within the organisation that affects the way they interact with each other and with stakeholders from outside the organisation". Cameron and Quinn (1999) advocate that organisational culture can be categorised into four (4) prevailing cultures: clan, market, hierarchy, and adhocracy culture.

In a clan culture, the emphasis is on teamwork. The organisation is structured in a way that provides friendly, supportive work environments. The organisation highly values its employees and customers (Cameron and Quinn, 1999).

In a market culture, the emphasis is on a competitive organisational environment. Employees are valued according to the values that they add, or produce in a competitive market place (Cameron and Quinn, 1999).

A hierarchy culture is driven by formalized, structured work environments. In this case, top-down management is adopted with emphasis placed on coordination. Thus, the management style is procedure driven (Cameron and Quinn, 1999).

The adhocracy culture is the opposite of the hierarchy culture. Organisations that adopt this culture are seen as dynamic, entrepreneurial, and creative places to work. In this type of organisation, innovation and experimentation are valued as employees creativity is encouraged (Cameron and Quinn, 1999).

It is important to note that Cameron and Quinn (1999) affirm that none of the above organisational profiles is superior to the others. In other words, all of these types of organisational cultures can be equally successful in terms of

2 SMMEs that have an internet connection and an email account

${ }^{3}$ SMMEs that have a website

${ }^{4}$ SMMEs that have moved beyond the starters' and innovators' stages. 
promoting organisational effectiveness. However, Grandon and Pearson (2004), in their study on Small and Medium businesses in USA, found that compatibility between e-commerce and firm's culture, values, and preferred work practices is one of the determining factors of e-commerce adoption. In addition, Seyal et al. (2004) found that organisational culture is a significant factor that influences the adoption of e-commerce in Pakistan SMMEs. Beatty et al. (2001) also found that organisations that perceive website use as compatible with the existing organisational culture, adopted e-commerce earlier than those perceiving some level of incompatibility between the two. Gibbs et al. (2003) and Teo and Ranganathan (2004) also found that organisational cultures that do not support innovation and the use of new technologies act as a barrier to B2B e-commerce adoption.

\subsection{Owner/manager characteristics}

The influence of the owner/manager in the technology adoption process is of paramount importance within the context of SMMEs. This stems from the fact that in most cases, the owner/manager is the sole decision maker in the company. Thus, the decision to adopt or not adopt an innovation (technology) depends largely on the owner/manager. This paper focuses on the owner/manager support of technology adoption and the owner/manager perception of the benefits derived from a technology as possible determinants of e-commerce amongst the surveyed SMMEs.

\subsubsection{Owner manager support of technology adoption}

Akkeren and Cavaye (1999) argue that SMME owners are primarily concerned with return on investment. This leads small firms to be more concerned about short to medium term viability of an investment rather than long term benefits. Therefore, substantial investments are often not released when there are no short-term benefits deriving from such investment. In addition, Qirim (2006:5) argues that "the loss of control of the business heightens the fear and anxiety of small business owners". Therefore, SMME owners may not be enthusiastic about adopting a technology that will result in loss of control of the business.

In addition, the decision to adopt a technology is also related to the perceived usefulness of such a technology from the owner's perspective. Kirby and Turner (1993) argue that the perception of the usefulness of a technology is often related to the knowledge that the owner has about the use of such technology. The knowledge about the technology will then inform the owner about the potential benefits of the technology in relation to the business. Such knowledge combined with the perceived benefits will determine whether the owner accepts and supports the implementation of the technology or not.

Corbitt et al. (1997) advocate that e-commerce is more of a management issue than a technical one. Many researchers have found that without the support of top executives, technology cannot be successfully implemented (Gagnon and Tolouse, 1996;Lambert, 1996;Cooper and Zmud, 1990;Kwon and Zmud, 1987;Manross and Rice, 1986). Top management is the key responsible agent for ensuring that strategic and operational rules that govern their business activities and e-commerce initiatives are in place. Therefore, in the context of SMMEs, owner support of a technology coupled with their perception of the potential benefits of e-commerce acts as a catalyst toward its adoption strategically and operationally. On one hand, strategically, e-commerce focuses on marketing, promotional and product/service strategies. On the other hand, operationally, e-commerce focuses on infrastructure, back-end support, logistics and customer services (Razi et al., 2004).

\subsection{Internal IT capabilities}

\subsubsection{Internal IT skills}

SMMEs require different skills as they progress up the e-commerce adoption ladder. At the bottom level of the stepwise adoption process, SMME employees should be able to operate e-mail. This requires minimal computer skills that can be obtained through computer short courses. In the next stages of the adoption process, as the SMME moves towards the setting up of a website and e-commerce functionalities embedded within it, maintenance of e-commerce infrastructure becomes complex, thus requiring expert skills. This is supported by Rogers (2003) as he states that if an innovation (technology) is deemed to be complex, then it needs to be managed by appropriately skilled professionals.

Caldeira and Ward (2003) advocate that staff training is one of the factors that influence e-commerce adoption. The training builds the necessary knowledge required within the company as it moves along the path towards ecommerce adoption. Employees will require different skills as the company moves towards full adoption of e-commerce. 
In this case, a strategy to adopt e-commerce is needed as it would highlight the need for various staff training programs or/and acquiring skilled staff especially in the early e-commerce adoption process. However, the importance of internal IT skills will vary according to the role that e-commerce plays within the company business strategy. If e-commerce is core to the business, the company might resort to develop in-house experts to set up and maintain the company e-commerce infrastructure. In other cases, an SMME could outsource all e-commerce set up and maintenance activities to an external third party. In this case, the SMME will exert a heavy reliance on support from vendors and the availability of consultants for the maintenance of both software and hardware required for the daily run of e-commerce activities (Ching and Ellis, 2004;Grandon and Pearson, 2004c);Caldeira and Ward, 2003).

\subsubsection{Availability of technological resources}

Technological resources available within the firm are also an important aspect of e-commerce adoption. They not only demonstrate the firm's readiness for e-commerce adoption but also indicate the stage at which the firm is in terms of ecommerce adoption. Applegate et al. (2009) advocate that there are three basic components of internetworking infrastructure: network, processing systems and facilities. Network refers to the hardware and software that allow the exchange of information between processing units and organisations. Here, in the context of e-commerce, the processing units can be understood as the hardware and software that processes the transactions when a customer pays through the company till point or through the company website. A firm can use a dedicated network or a secure internet connection. Processing systems include the hardware and software that, in conjunction, allow an organisation to handle business transactions. These include but are not limited to computers and databases. A database is a repository used to store and extract data. Facilities depict the "physical systems that house and protect computing and network devices" (Applegate et al., 2009:241). However, Applegate et al. (2009) argue that facilities should cater for high levels of availability, reliability and security. This means that facilities should be designed to ensure that data and information requested by users whilst interacting with or performing e-commerce transactions are available when needed, accurately and securely transmitted over the network.

\subsubsection{Availability of financial resources}

Beatty, Shim and Jones (2001) argue that the likelihood of e-commerce adoption and the migration of offline transactions into a network-based platform are linked to the firms' web budget. E-commerce budget allocation is linked to its strategic use and its position within the strategic goals of a company. Research has confirmed that a number of SMMEs adopt ICT in response to a trigger (ad hoc) (Antlová, 2009). This could mean that there is no initial budget allocation unless ecommerce has been incorporated within the company overall business strategy. However, the allocation of IT budget is meant to be proportional to the role that IT plays in the company core business (Applegate et al., 2009). Lower budgets are likely to be allocated to e-commerce implementation if it is solely implemented for supporting the day-to-day transactions (Applegate et al., 2009). A gradual increment in e-commerce budget allocation is likely to be seen as ecommerce evolves to be part of the overall company strategy as it is used to achieve the company strategic goals (Applegate et al., 2009). Moreover, budget allocation for e-commerce purposes will determine the stage at which the firm is situated on the adoption ladder. The financial resources are allocated to e-commerce, the more the firm is likely to move from just having an internet presence to web based functionalities such online transaction processing and onlineintegrated supply chain.

\section{Methodology}

Based on literature search, the following factors were identified as internal factors that influence e-commerce adoption: Firm's characteristics, Owner/manager characteristics and Internal IT capabilities. The influence of these factors on the adoption of the following 4 e-commerce was then assessed: i) customers payment by credit card through the SMME's website, ii) customers placing orders through the SMME's website, iii) providing customer services through the SMME's website and iv) placing orders with suppliers over the internet. Using convenience sampling, data was collected by means of questionnaires administered to 400 SMME owners/managers. Usable responses were collected from 360 SMME owners/managers. This represents a $90 \%$ response rate. 


\section{Findings}

\subsection{Crosstabulation between firm's size and e-commerce adoption}

Table 1.Cross tabulation between e-commerce adoption and size of the business (Number of full-time employees)

\begin{tabular}{|c|c|c|c|c|}
\hline \multirow{2}{*}{\multicolumn{2}{|c|}{ What is the approximate number of full-time employees in your company? }} & \multicolumn{2}{|c|}{ The company has adopted E-Commerce } & \multirow{2}{*}{ Total } \\
\hline & & Yes & No & \\
\hline \multirow{2}{*}{ Less than 10} & Count & 16 & 131 & 147 \\
\hline & $\%$ & $10.7 \%$ & $63.6 \%$ & $41.3 \%$ \\
\hline \multirow{2}{*}{10 to 50} & Count & 46 & 52 & 98 \\
\hline & $\%$ & $30.7 \%$ & $25.2 \%$ & $27.5 \%$ \\
\hline \multirow{2}{*}{51 to 100} & Count & 60 & 21 & 81 \\
\hline & $\%$ & $40.0 \%$ & $10.2 \%$ & $22.8 \%$ \\
\hline \multirow{2}{*}{101 to 200} & Count & 28 & 2 & 30 \\
\hline & $\%$ & $18.7 \%$ & $1.0 \%$ & $8.4 \%$ \\
\hline \multirow{2}{*}{ Total } & Count & 150 & 206 & $356^{*}$ \\
\hline & $\%$ & $100.0 \%$ & $100.0 \%$ & $100.0 \%$ \\
\hline
\end{tabular}

4 respondents did not disclose the number of full time employees in their companies

Table 1 depicts a crosstabulation between e-commerce adoption and the size of the business (total number of full-time employees within SMMEs). The table indicates that the majority $(40.0 \%, \mathrm{~N}=60)$ of surveyed SMMEs that adopted any of the four e-commerce options have between 51 and 100 full-time employees in their businesses. However, the majority of those that have not adopted e-commerce have less than 10 employees. A Chi square test applied to the crosstabulation reveals that there is a significant relationship between e-commerce adoption and the size of SMMEs $(125.952, \mathrm{df}=3$, $p=0.000)$. Specifically, significantly $(p<0.05)$ more than expected SMMEs that employ between 51 and 100 have adopted e-commerce. However, significantly $(p<0.05)$ more than expected SMMEs that employ less than 10 full-time employees have not adopted e-commerce.

The size of a business as a determinant of e-commerce has implications for e-commerce adoption within each location. The majority $(53.9 \%, \mathrm{~N}=96)$ of SMMEs in Durban have less than 10 employees whilst the majority (34.3\%, $\mathrm{N}=61$ ) of SMMEs in Pietermaritzburg have between 51 and 100 employees. Consequently, the number of SMMEs that adopted e-commerce in Pietermaritzburg is greater than those that adopted e-commerce in Durban.

In terms of the South African Classification of SMMEs (National Small Business Amendment Act, 2003), the results show that the majority of e-commerce adopters are medium enterprises (51 and 100). However, the majority of nonadopters are micro businesses (less than 5 employees) and to a certain extent small businesses (between 6 and 50 employees). 
Table 2. Cross tabulation between e-commerce adoption and size of the business (Total annual turnover)

\begin{tabular}{|c|c|c|c|c|}
\hline \multirow{2}{*}{\multicolumn{2}{|c|}{ What is the approximate annual turnover of your company? }} & \multicolumn{2}{|c|}{ The company has adopted E-Commerce } & \multirow{2}{*}{ Total } \\
\hline & & Yes & No & \\
\hline Less than $\mathrm{R} 100,000$ & $\begin{array}{c}\text { Count } \\
\%\end{array}$ & $\begin{array}{c}6 \\
4.2 \%\end{array}$ & $\begin{array}{c}50 \\
29.8 \%\end{array}$ & $\begin{array}{c}56 \\
17.9 \% \\
\end{array}$ \\
\hline R 100,000 to 300,000 & $\begin{array}{c}\text { Count } \\
\%\end{array}$ & $\begin{array}{c}10 \\
6.9 \%\end{array}$ & $\begin{array}{c}41 \\
24.4 \% \\
\end{array}$ & $\begin{array}{c}51 \\
16.3 \% \\
\end{array}$ \\
\hline R 300,001 to $R 500,000$ & $\begin{array}{c}\text { Count } \\
\%\end{array}$ & $\begin{array}{c}12 \\
8.3 \% \\
\end{array}$ & $\begin{array}{c}28 \\
16.7 \% \\
\end{array}$ & $\begin{array}{c}40 \\
12.8 \% \\
\end{array}$ \\
\hline R 500,001 to $R 1,000,000$ & $\begin{array}{c}\text { Count } \\
\%\end{array}$ & $\begin{array}{c}27 \\
18.8 \% \\
\end{array}$ & $\begin{array}{c}20 \\
11.9 \% \\
\end{array}$ & $\begin{array}{c}47 \\
15.1 \% \\
\end{array}$ \\
\hline $1,000,001$ to $R 2,000,000$ & $\begin{array}{c}\text { Count } \\
\% \\
\end{array}$ & $\begin{array}{c}44 \\
30.6 \% \\
\end{array}$ & $\begin{array}{c}8 \\
4.8 \% \\
\end{array}$ & $\begin{array}{c}52 \\
16.7 \% \\
\end{array}$ \\
\hline $2,000,001$ to $R 3,000,000$ & $\begin{array}{c}\text { Count } \\
\% \\
\end{array}$ & $\begin{array}{c}24 \\
16.7 \% \\
\end{array}$ & $\begin{array}{c}7 \\
4.2 \% \\
\end{array}$ & $\begin{array}{c}31 \\
9.9 \% \\
\end{array}$ \\
\hline Above $\mathrm{R} 3,000,000$ & $\begin{array}{c}\text { Count } \\
\%\end{array}$ & $\begin{array}{c}21 \\
14.6 \%\end{array}$ & $\begin{array}{c}14 \\
8.3 \%\end{array}$ & $\begin{array}{c}35 \\
11.2 \%\end{array}$ \\
\hline Total & $\begin{array}{c}\text { Count } \\
\%\end{array}$ & $\begin{array}{c}144 \\
100.0 \%\end{array}$ & $\begin{array}{c}168 \\
100.0 \%\end{array}$ & $\begin{array}{c}312^{*} \\
100.0 \%\end{array}$ \\
\hline
\end{tabular}

48 respondents did not disclose the approximate annual turnover of their companies

In terms of the annual turnover (as a second measure of the size of the business), the findings in table 2 above also reveal that SMMEs with a total turnover between R 100,000 and R 1,000,000 account only for $38.2 \%$ of those that adopted e-commerce. However, the majority (61.8\%) of SMMEs that adopted e-commerce have a minimal annual turnover of above R1, 000,000.

The above further concurs with findings from previous research on e-commerce adoption (Van Beveren and Thomson, 2002; Hong and Zhu, 2006) that confirms the importance of business size as an important factor to consider within the context of SMMEs.

\subsection{Association between firm's culture and e-commerce adoption}

The following factors were tested as possible firm's culture factors that could influence the adoption of e-commerce in Pietermaritzburg and in Durban: compatibility with existing company's organisational culture (COC), compatibility with company values (COV), and compatibility with company's preferred work practices (COPWP).

Table 3. Summary of Chi square tests between firm's culture and e-commerce adoption. (The table shows the p values*)

\begin{tabular}{|c|c|c|c|c|c|c|c|c|}
\hline & \multicolumn{2}{|c|}{$\begin{array}{l}\text { Online payment by credit } \\
\text { card }\end{array}$} & \multicolumn{2}{|c|}{ Online ordering } & \multicolumn{2}{|c|}{$\begin{array}{l}\text { Customer } \\
\text { services }\end{array}$} & \multicolumn{2}{|c|}{$\begin{array}{l}\text { Placing orders with suppliers through the } \\
\text { internet }\end{array}$} \\
\hline & DBN & PMB & DBN & PMB & DBN & PMB & DBN & PMB \\
\hline $\mathrm{COC}$ & 0.969 ** & $0.066^{* \star}$ & $0.076^{\star \star}$ & $0.698^{* *}$ & $0.497^{* *}$ & $0.499^{* \star}$ & $0.180^{* *}$ & $0.300^{\star \star}$ \\
\hline COV & $0.501^{* *}$ & $0.208^{* *}$ & $0.246^{* *}$ & $0.742^{\star *}$ & $0.315^{\text {** }}$ & $0.396^{\star *}$ & $0.032^{* *}$ & $0.216^{\star \star}$ \\
\hline COPWP & $0.080^{* *}$ & $0.018^{\star \star}$ & $0.300^{* *}$ & $0.518^{\star *}$ & $0.588^{* *}$ & $0.642^{\star \star}$ & $0.509^{* *}$ & $0.147^{\star *}$ \\
\hline
\end{tabular}

${ }^{*} p<0.05=$ significant relationship; $p>=0.05=$ no significant relationship

${ }^{* *}$ Fisher's test (more than $20 \%$ of data has count less than 5 )

The summary table above shows that:

In Pietermaritzburg, the relationship between company's preferred work practices and online payment by credit card is the only significant $(\mathrm{p}<0.05)$ relationship. Specifically, the majority $(66.3 \%, \mathrm{~N}=61)$ of SMMEs that allow customers to pay by credit card through their websites agree that compatibility with company's preferred work practices has influenced the decision to adopt e-commerce in their companies.

In Durban, the relationship between placing orders with suppliers through the internet and compatibility with company values is the only significant relationship. In addition, the majority $(68.2 \%, \mathrm{~N}=75)$ of SMMEs that place orders with suppliers over the internet agree that compatibility with company values has influenced the decision to adopt ecommerce in their companies. 


\subsection{Association between owner manager characteristics and e-commerce adoption}

Variable 1 (OMS): Owner manager support

Variable 2 (OME): Owner/manager enthusiasm about e-commerce adoption

Table 4. Summary of Chi square tests between OMS\&OME and e-commerce adoption. (The table shows the $p$ values*)

\begin{tabular}{|c|c|c|c|c|c|c|c|c|}
\hline & \multicolumn{2}{|c|}{$\begin{array}{l}\text { Online payment by credit } \\
\text { card }\end{array}$} & \multicolumn{2}{|c|}{ Online ordering } & \multicolumn{2}{|c|}{$\begin{array}{l}\text { Customer } \\
\text { services }\end{array}$} & \multicolumn{2}{|c|}{$\begin{array}{c}\text { Placing orders with suppliers over the } \\
\text { internet }\end{array}$} \\
\hline & DBN & PMB & DBN & PMB & DBN & PMB & DBN & PMB \\
\hline OMS & $0.319^{\star *}$ & 0.244 & $0.552^{\star \star}$ & 0.978 & $1.000^{\star \star}$ & $0.918^{\star \star}$ & $0.338^{\star \star}$ & 0.837 \\
\hline OME & $0.048^{\star \star}$ & $0.166^{\star \star}$ & .083 & 0.462 & $0.331^{\star \star}$ & $0.862^{\star \star}$ & $0.230^{\star \star}$ & $0.875^{\star \star}$ \\
\hline
\end{tabular}

${ }^{*} p<0.05=$ significant relationship; $p>=0.05=$ no significant relationship

${ }^{* *}$ Fisher's test (more than $20 \%$ of data has count less than 5 )

The Chi square test results depicted in table 4 show that the relationship between top management enthusiasm about ecommerce adoption (OME) and online credit card payment is the only significant relationship. Such relationship is significant in Durban $(\mathrm{p}<0.05)$ only. The corresponding crosstabulation results indicate that the majority $(70 \%, \mathrm{~N}=21)$ of SMMEs that allow customers to pay by credit card through their websites in Durban agree that their top management is enthusiastic about e-commerce adoption. However, no significant $(p>0.05)$ relationship was found between OMS and ecommerce adoption.

\subsection{Association between internal IT capabilities and e-commerce adoption}

The following variables were used to assess the influence of internal IT capabilities on e-commerce adoption: Presence of IT Skills (PIS), Availability of Financial Resources (AFR) and Availability of Technological Resources (ATR).

Table 5. Summary of Chi square tests between internal IT capabilities and each of the e-commerce options. (The table shows the $p$ values*)

\begin{tabular}{|l|c|c|c|c|c|c|}
\hline \multirow{2}{*}{} & \multicolumn{2}{|c|}{ PIS } & \multicolumn{2}{|c|}{ AFR } & \multicolumn{2}{c|}{ ATR } \\
\cline { 2 - 6 } & DBN & PMB & DBN & PMB & DBN & PMB \\
\hline Online payment by credit card & 0.576 & $0.358^{\star \star}$ & $0.636^{\star \star}$ & $0.374^{\star \star}$ & $0.446^{\star \star}$ & $0.692^{\star \star}$ \\
\hline Online ordering & $0.699^{\star \star}$ & $1.000^{\star \star}$ & $0.60^{\star \star}$ & $0.119^{\star \star}$ & $0.314^{\star \star}$ & $0.719^{\star \star}$ \\
\hline Customer services & $0.384^{\star \star}$ & $0.932^{\star \star}$ & $1.000^{\star \star}$ & $0.084^{\star \star}$ & $0.664^{\star \star}$ & $1.000^{\star \star}$ \\
\hline Placing of orders with suppliers through the internet & $0.684^{\star \star}$ & $0.605^{\star \star}$ & $0.085^{\star \star}$ & $0.135^{\star \star}$ & $0.749^{\star \star}$ & $0.557^{\star \star}$ \\
\hline
\end{tabular}

${ }^{*} p<0.05=$ significant relationship; $p>=0.05=$ no significant relationship

${ }^{* *}$ Fisher's test (more than $20 \%$ of data has count less than 5 )

The results of the Chi square tests depicted in table 5 above indicate that there is no significant relationship ( $p>0.05)$ between internal IT capabilities and each of the e-commerce options.

\section{Discussion and Recommendations}

The research found that the size of the SMME is still an important factor in the adoption of e-commerce. The larger the SMME, the more it is likely to adopt e-commerce. A similar finding was obtained by Al-Qirim (2007) through his research on e-commerce adoption by SMMEs in New Zealand. Goldstuck (2012) indicates that a survey of SMMEs in South Africa reveals that having a website depends on the size or for how long the SMME has been in business. He states that "the larger an organisation, or the longer it has been around for, the more likely it is to have a website"(Goldstuck, 2012:11). Since SMMEs must have a website in order to adopt web-related e-commerce, it makes sense that the larger the SMME, the more likely it is to adopt web-based e-commerce.However, SMMEs need to be encouraged to have an online presence in the early stage of their existence. This could contribute to the increase of the number of SMMEs businesses that thrive to the maturity level.Such could be done through various awareness programs that may be executed as part of the SMMEs support initiatives. Compatibility with company's preferred work practices and values was also found to be catalysts towards e-commerce adoption. Hence, these programs should also stimulate the introduction of values and work practices that encourage e-commerce adoption.

The findings also reveal that top management enthusiasm about e-commerce adoption is a significant factor that 
stimulates e-commerce adoption. Due to SMME's heavy reliance on the owner/manager as the sole decision maker, it is imperative to stimulate the owner/manager enthusiasm towards e-commerce adoption. Specifically, there is a need to devise SMMEs support programs that emphasize the benefits that the owner/manager's business may get as a result of owner/manager's acceptance to adopt e-commerce.

\section{References}

Akkeren, J. \& Cavaye, A. (1999). Factors Affecting the Adoption of E-commerceTechnologies by Small Businesses in Australia-An Empirical study. [Online]Available:http://www.acs.org.au/act/events/io1999/akkern.html [January 14, 2011].

Al Qirim, N. (2005). An Empirical Investigation of an E-commerce Adoption-Capability Model in Small Businesses in New Zealand. Electronic Markets, 15, 418-437.

Antlová, K. (2009). Motivation and barriers of ICT adoption in small and medium-sized enterprises. [Online]. Available:http://www.ekonomiemanagement.cz/download/1331826716 d7e9/11-antlova.pdf [November 26, 2012].

Applegate, M., Austin, R. D. \& Mcfarlan, F. W. (2009). Corporate InformationStrategy and Management: Text and Cases .New York:McGraw-Hill InternationalEdition.

Beatty, R. C., Shim, J. P. \& Jones, M. C. (2001). Factors influencing corporate web siteadoption: a time-based assessment. Information and Management, 38, 337-354.

Caldeira , M. M. \& Ward, J. M. (2003). Using resource-based theory to interpret thesuccessful adoption and use of information systems and technology in manufacturingsmall and medium-sized enterprises. European Journal of Information Systems, 12,127-141.

Cameron, K. \& Quinn, R. (1999). Diagnosing and changing organizational culture: Basedon the competing values framework.Boston: AddisonWesley, Reading.

Ching, H. \& Ellis, P. (2004). Marketing in cyberspace: What factors drive e-commerceadoption? Journal of Marketing Management, $20,409-430$.

Cooper, R. \& Zmud, R. (1990). Information Technology Implementation Research: A Technology Diffusion Approach. Management Science, 36, 123-139.

Dharmayanti, G., Coffey, V. \& Trigunarsyah, B. (2011). The Importance of Organisational Culture to improve a Project Selection Process: Case of Public Infrastructure Project in Indonesia. In Taplin, J. (ed.), Towards Liveable Cities \& Better Communities (pp. 1-11). Australia: Smart Vision International.

Gagnon, Y. \& Tolouse, J. (1996). The behaviour of business managers when adopting newtechnologies. Technological Forecasting and Social Change, 52, 59-74.

Gibbs, J., Kraemer, K. L. \& Dedrick, J. (2003). Environment and policy factors shaping global E-commerce diffusion: A cross-country comparison. Inf. Soc., 19, 5-18

Goldstuck, A. (2012). Internet Matters: The Quiet Engine of the South African Economy. [Online] Available: http://www. internetmatters.co.za/report/ZA Internet Matters.pdf (July 12, 2014)

Grandon, E. E. \& Pearson, J. M. (2004). Electronic Commerce Adoption: An EmpiricalStudy of Small and Medium US Businesses. Information and Management, 42, 197-216

Hong, W. \& Zhu, K. (2006). Migrating to internet-based e-commerce: factors affecting E-commerce adoption and migration at the firm level. Information and Management, 43, 204-221.

lab (2014). South African Mobile Report. [Online] available:http://www.sabc.co.za/wps/wcm/connect/68746d0043a866399d42fda 602140 f6d/South_Africa_Mobile_Report-Mar14.pdf?MOD=AJPERES\&CACHEID=68746d0043a866399d42fda602140f6d (July 11, 2014)

Kirby, D. \& Turner, M. (1993). IT and the small retail business. International Journal ofRetail and Distribution Management, 21, 20-27.

Kwon, T. \& Zmud, R. (1987). Unifying the fragmented models of information system implementation. In Boland, R. \& Hirschheim, R. (eds), Critical issues in information system research (227 - 251). New York: John Wiley

Lambert, B. (1996). Data warehousing fundamentals: What do you need to know to succeed. [Online]. Available: http://www.datawarehouse.com/resource/articles/lamb8.htm[Accessed 30 September 2011].

Macgregor, R. C. \& Vrazalic, L. (2005). A basic model of electronic commerce adoption barriers: a study of regional small businesses in Sweden and Australia. Journal of Small Business and Enterprise Development, 12, 510-527.

Manross, G. \& Rice, R. (1986). Don't Hang Up: Organisational Diffusion of the Intelligent Telephone. Information and Management, 10, $161-175$.

Poon, S. \& Swatman, P. M. C. (1999). An Exploratory Study of Small Business Internet Commerce Issues. Information and Management, 35, 9-18.

PRC (2014). Emerging Nations Embrace Internet, Mobile Technology. [Online] Available:http://www.pewglobal.org/2014/02/13 /emerging-nationsembrace-internet-mobile-technology/ (July 11, 2014)

Qirim, A. (2006). Global electronic business research: opportunities and directions (ed.).Hershey: PA, Idea Group.

Razi, M. A., Tarn, J. M. \& Siddiqui, F. A. (2004). Exploring the Failure and Success of Dotcoms. Information and Management \& Computer Security, 12, 228-244

Rogers, E. 2003. Diffusion of Innovations.New York: Free Press.

Saffu, K., Walker, J. H.\& Hinson, R. (2008). Strategic value and electronic commerce adoption among small and medium-sized enterprises in a transitional e-conomy. The Journal of Business and Industrial Marketing, 23, 395-404.

Schaper, M. \& Volery, T. (2004). Entrepreneurship and small business: A Pacific RimPerspective. Australia: John Wiley \& Sons Australia, Ltd.

Seyal, A. H., Awais, M. M., Shamail, S. \& Abbas, A. (2004). Determinants ofElectronic Commerce in Pakistan: Preliminary Evidence from Small and MediumEnterprises. Electronic Markets, 14, 372-387.

Teo, T. \& Ranganathan, C. (2004). Adopters and non-adopters of business-to-business electronic commerce in Singapore. Information and Management, 42, 89-102.

Van Beveren, J. \& Thomson, H. (2002). The use of electronic commerce by SMEs in Victoria. Journal of Small Business Management, 40, $250-253$. 